Missio Ecclesiae, 3 (2), Oktober 2014, 183-198

\title{
DAMAI SEJAHTERA MENANTI KIAMAT \\ Matius 25:14-30
}

\section{Awasuning Manaransyah}

\section{PENDAHULUAN}

Kiamat merupakan satu isu yang tidak ada habis-habisnya dibicarakan dari waktu ke waktu. Kiamat selalu digambarkan dengan keadaan yang sangat mengerikan, yang mana terjadi kehancuran bumi dan kebinasaan seluruh makhluk hidup. Sehingga ketika seseorang mendengar istilah kiamat, maka yang muncul dalam pikirannya adalah suatu gambaran peristiwa yang sangat menyeramkan dan menakutkan. Tapi saya yakin bahwa Saudara sudah pernah mendengar begitu banyak isu tentang datangnya kiamat. Dan respon setiap orang yang mendengar isu itu pun berbeda-beda.

Ramalan tentang kiamat 21 Desember 2012 menjadi isu yang paling spektakuler di seluruh belahan dunia. Mengapa? Pada akhir tahun 2009, dunia gempar dengan munculnya film 2012 yang sangat fenomenal. Film hasil produksi Hollywood ini berhasil menarik ratusan juta penonton di seluruh dunia. Hal ini tentu saja sangat menguntungkan bagi perusahaan perfilman. Berbondong-bondong manusia memasuki gedung bioskop, silih berganti karena ingin mengetahui bagaimana kiamat yang digambarkan dalam film tersebut, berhubung jarak antara tahun 2009 dengan tahun 2012 sangat dekat.

Banyak orang yang bertanya, benarkah kiamat akan terjadi pada tahun 2012? Munculnya film ini juga mengundang reaksi penolakan keras dari tokoh-tokoh agama, terutama dari kalangan Muslim. Para ulama melarang keras umatnya untuk menonton film yang menurut mereka dapat menyesatkan iman para penganut agama Islam. Selain dari pada itu, akhirnya banyak cendikiawan yang akhirnya melakukan penelitian, baik itu di bidang ilmu pengetahuan, budaya maupun di bidang agama untuk memastikan bahwa kiamat 2012 hanyalah isu isapan jempol yang tidak berdasar.

Isu kiamat 2012 menjadi sangat spektakuler oleh karena negara Mexico

justru menawarkan Wisata Kiamat, dengan mengunjungi beberapa tempat/ 
Missio Ecclesiae, 3 (2), Oktober 2014, 183-198

wilayah dimana suku Maya tinggal dan beberapa situs-situs ritual suku ini, termasuk kuilnya.

\section{PENGERTIAN KIAMAT SECARA UMUM}

Berdasarkan Kamus Bahasa Indonesia, kiamat dalam bentuk kata benda artinya hari kebangkitan sesudah mati, yaitu orang yang telah meninggal dihidupkan kembali untuk diadili perbuatannya. Selain itu juga berarti hari akhir zaman dimana dunia dan isinya rusak binasa dan lenyap. Sedangkan dalam bentuk kata kerjanya diartikan berakhir, tidak akan muncul lagi atau juga dapat berarti celaka sekali, bencana besar, rusak binasa. ${ }^{1}$ Dengan demikian, kiamat secara sederhana dimengerti sebagai hari berakhirnya kehidupan dunia ini yang ditandai dengan kehancuran bumi dan benda angkasa, bersamaan dengan bangkitnya kembali orang-orang yang telah meninggal untuk diadili perbuatannya yang pernah dilakukan selama hidupnya.

Kiamat juga sering disebut dengan akhir zaman, hari penghakiman terakhir atau hari Tuhan. Dalam bahasa Inggris disebut end of the days, yang memiliki pengertian demikian: "when everything is taken into consideration".2 Pengertian-pengertian tersebut di atas tentu masih sangat umum sifatnya. Jika kiamat berbicara tentang akhir dari kehidupan, maka saya mencoba membuat klasifikasi kiamat, yaitu:

1. Kiamat yang bersifat personal: tidak ada kaitannya dengan akhir zaman dunia ini, apalagi dengan kedatangan Tuhan Yesus yang kedua kali. Kiamat personal menyangkut tentang kematian atau akhir hidup seseorang di dunia. Dalam Alkitab, misalnya Kej 5 yang mencatat tentang kematian orang-orang semasa 10 generasi. Kejadian 23:23:7-8 tentang kematian Abraham. Kejadian 35:28-29, tentang kematian Ishak. Kejadian 49:33, tentang kematian Yakub. Kejadian 50:26, tentang kematian Yusuf. Ulangan 34 tentang kematian Musa, Yosua 24:29 tentang kematian Yosua dan sebagainya. Seluruh teks ini menunjuk kepada akhir hidup dari seseorang. ${ }^{3}$

\footnotetext{
${ }^{1}$ http://kamusbahasaindonesia.org/kiamat\#ixzz2K5ClqBq2

2 Concise Oxford English Dictionary,

3 Peter Wongso, Hermeneutika Eskatologi, (Malang: SAAT, 2000), 5
} 
Missio Ecclesiae, 3 (2), Oktober 2014, 183-198

Alkitab yang kita percayai sebagai Firman Allah, telah membukakan suatu kebenaran yang nyata, yaitu bahwa setiap orang/ manusia pasti memiliki masa hidup yang terbatas, dalam arti bahwa semua orang pasti akan berakhir hidupnya alias meninggal dunia. Namun tidak ada satu orang pun yang mengetahui kapan ajalnya akan tiba. Maka setiap orang mau tidak mau; suka tidak suka harus menyiapkan dirinya untuk meninggal suatu saat yang tidak diketahui mengenai tanggal, hari dan jamnya dan bagaimana cara kematian itu akan datang. Dengan kata lain, tidak ada seorang pun yang mampu menunda kematian dan tidak seorang pun yang berhak mempercepat kematiannya. Hal tersebut hanyalah kesia-siaan dan kebodohan yang merupakan dosa di hadapan Tuhan. Namun demikian, kita tidak dapat menutup mata terhadap kenyataan bahwa adanya upaya-upaya di bidang medik yang berusaha memenuhi keinginan para pasiennya. Mereka melakukan berbagai penelitian untuk menghasilkan peralatanperalatan yang mutakhir guna memperlambat proses kematian seseorang. Kelihatannya memang sangat baik, namun jika dikaji lagi, maka itu hanya akan menimbulkan kerugian yang luar biasa. Keadaan si pasien sepertinya semakin baik, namun sesungguhnya dia justru mengalami kesakitan yang sangat menyiksa dia. Di sisi lain, pihak keluarga akan berusaha keras untuk mendapatkan uang sebanyakbanyaknya supaya dapat membayar biaya pengobatan yang sangat mahal. Lalu di mana letak keuntungannya???

Di sisi lain, ada juga penawaran di bidang medik untuk membantu pasien (keluarganya?) supaya si pasien cepat meninggal dengan cara perlahan dan tidak mengalami penderitaan karena penyakit. Hal ini disebut euthanasia. Kemungkinan hal ini dilakukan karena merasa kasihan kepada pasien yang sangat menderita atas penyakit yang dialami, atau juga mungkin keluarga telah menyerah karena tidak lagi sanggup membiayai pengobatan dan perawatan yang begitu mahal. Sebagaimana kelahiran dan kehidupan manusia telah dirancang oleh Tuhan sedemikian rupa, demikian juga dengan kematian manusia. Hidup dan matinya manusia adalah kehendak dan rencana Tuhan, baik berkenaan dengan waktu, tempat dan cara matinya seseorang. 
Missio Ecclesiae, 3 (2), Oktober 2014, 183-198

2. Kiamat Komunal yang dimaksud adalah kematian sejumlah besar manusia dalam waktu yang bersamaan akibat adanya bencana yang terjadi. Kita tentu mengingat peristiwa Tsunami di Aceh, gempa berskala besar di Nias, Jogjakarta, gunung meletus, longsor, kebakaran rumah-rumah, hutan dan lain sebagainya, yang memakan korban jiwa. Selain bencana alam, juga bencana perang dan kelaparan baik karena perang, maupun karena terjadinya kekeringan sehingga tidak tersedianya bahan-bahan makanan yang dibutuhkan. Sekalipun organisasi besar yang bersifat internasional, seperti PBB selalu berupaya untuk mengirimkan bantuan pangan, namun tidak dapat menghentikan kematian dari sejumlah orang oleh bencana kelaparan tersebut.

3. Kiamat global adalah kiamat yang akan dibahas secara panjang lebar dalam buku ini. Karena kiamat global menyangkut kesudahan zaman dimana nubuatan Tuhan Yesus akan terjadi.

\section{DAMAI SEJATERA MENANTIKAN KIAMAT}

\section{Pengertian Kiamat dalam Alkitab}

Tuhan Yesus secara khusus menkhotbahkan tentang kiamat yang dalam bahasa Alkitabnya Akhir Zaman. Yang paling jelas dan khusus, pengajaran tentang akhir zaman ini dikhotbahkan oleh Tuhan Yesus kepada para murid menjelang akhir pelayanan-Nya. Hal ini dapat kita baca dalam kitab Matius 2425. Pada pasal 24:3, para murid bertanya kepada Tuhan Yesus tentang tandatanda dari dua hal, yaitu tanda kedatangan Tuhan Yesus dan tanda kesudahan dunia.

Hal yang sangat menarik kita lihat dari hal ini, yaitu para murid menghubungkan antara kedatangan Tuhan Yesus dengan kesudahan dunia. Tuhan Yesus berjanji kepada para murid, dan tentu kepada kita juga sebagai orang percaya yang adalah murid Tuhan Yesus, demikian: "Aku pasti datang kembali". Istilah ini senada dengan perkataan Tuhan Yesus: "Anak Manusia datang di atasa awan-awan di langit" (Matius 24:30), "kedatangan Anak Manusia" (Matius 24:37,39), "Anak Manusia datang" (Matius 24:44), "tuannya itu datang" (Matius 24:46,48,50), "mempelai datang” (Matius 25:6), 
Missio Ecclesiae, 3 (2), Oktober 2014, 183-198

"pulanglah hamba-hamba tuan itu" (Matius 25:19), "Anak manusia datang dalam kemuliaan-Nya dan semua malaikat bersama-sama dengan Dia" (Matius 25:31, 26:14). Semua istilah tersebut digunakan untuk menunjuk kepada kedatangan Tuhan Yesus yang kedua kali.

Selain dari pada itu, dalam Alkitab juga kita menemukan tanda-tanda kedatangan Tuhan Yesus yang kedua kali. Wongso membagi tanda-tanda kedatangan Tuhan Yesus yang kedua kali menjadi dua macam, yaitu: tandatanda yang bersifat universal (global) dan tanda-tanda yang bersifat gerejawi/keagamaan. ${ }^{4}$ Namun, saya tidak akan menguraikan hal-hal tersebut pada kesempatan ini, saya akan lebih memfokuskan pada bagaimana kita menjalani hidup dalam menantikan kedatangan Tuhan Yesus yang kedua kali.

\section{Apa yang harus dilakukan dalam menantikan kiamat}

\section{"MENGELOLA KEPERCAYAAN TUHAN"}

Dalam teks ini dituliskan bahwa hal kerajaan Sorga seperti seorang yang mau bepergian ke luar negeri, yang memanggil dan mempercayakan hartanya kepada hamba-hambanya. Kata "mempercayakan" dalam bahasa Yunani adalah pare, dwken (paredoken) dengan bentuk kata kerja orang ke-3 tunggal Aorist Aktif Indikatif ${ }^{5}$ dari kata dasar paradidwmi (paradidomi) yang muncul sebanyak 119 kali dalam Perjanjian Baru. Artinya adalah menyerahkan, mengkhianati, menyampaikan, meneruskan, mengajar, mengizinkan. ${ }^{6}$ Dalam NIV dipakai kata entrusted, yang dalam Oxford Advance Learner's Dictionary dijelaskan to give responsibility. ${ }^{7}$ Hasan Sutanto menerjemahkan: menyerahkan. Bentuk kata paredoken menyatakan suatu tindakan yang hanya dilakukan satu kali saja (tidak berulang-ulang) di masa lampau dan dianggap sudah selesai. Hal ini dapat juga ditafsirkan sebagai "kesempatan" karena tidak akan pernah terulang lagi. Sang tuan menyerahkan/mempercayakan hartanya kepada hambanya bukan suatu

\footnotetext{
${ }^{4}$ Peter Wongso, Hermeneutika Eskatologi, (Malang: SAAT, 2000), 291-299

${ }^{5}$ Hasan Sutanto, Perjanjian Baru Interlinear dan Konkordansi Perjanjian Baru Jilid I, (Jakarta: LAI, 2006), 147

${ }^{6}$ Hasan Sutanto, Perjanjian Baru Interlinear dan Konkordansi Perjanjian Baru Jilid II..., 605

7 Jonathan Crowther, Oxford Advanced Learner's Dictionary, (England: Oxford University Press, 1995), 386
} 
tindakan yang berulang-ulang, melainkan hanya satu kali dan hal ini menjadi satu kesempatan yang sangat berharga bagi para hamba. Istilah hamba yang digunakan pada teks ini adalah doulous dari kata dasar yang berarti "hamba, pegawai raja, orang yang bergantung pada" 8 sesorang atau sesuatu.

Jika seorang tuan rela mempercayakan hartanya kepada orang yang berstatus sosial rendah, maka sesungguhnya hal itu suatu kesempatan emas bagi seorang hamba membuktikan integritas, dedikasi dan loyalitasnya kepada sang tuan selama kepergian tuannya. Karena bagaimanapun pada akhirnya yang diminta adalah kesiapan si hamba untuk mempertanggungjawabkan apa yang telah dipercayakan itu. Hal ini berarti bahwa dalam masa penantian kedatangan sang tuan, hambanya tidak menantikan dengan pasif melainkan menerimanya dengan bekerja keras dan membuat lebih banyak kesempatan yang dipercayakan. ${ }^{9}$ Satu prinsip yang tidak boleh kita abaikan dari teks ini adalah bahwa sang tuan memberikan talenta itu "masing-masing menurut kesanggupannya" (ay.15). Itu berarti bahwa tuan itu mengetahui batas-batas kesanggupan dari tiap-tiap hambanya dan karena pengenalan yang baik sang tuan terhadap tiap-tiap pribadi hamba-hambanya. Dari hal tersebut, kita dapat mengerti bahwa tidak ada tekanan-tekanan yang berlebihan dari sang tuan kepada hamba-hambanya. Aplikasinya bagi kita orang percaya sebagai hamba Tuhan adalah:

1) Allah mempercayakan "harta-Nya" kepada kita, sesuai dengan kesanggupan kita karena Tuhan mengenal kita jauh sebelum kita mengenal siapa diri kita dan Ia mengenal kita lebih dalam dari pengenalan kita akan diri kita sendiri.

2) Kita tidak boleh bersungut-sungut ataupun merasa iri hati kepada orang lain yang mungkin kita lihat memiliki lebih banyak kelebihan atau talenta dari pada kita. Tuhan tahu apa dan mana yang pas untuk kita masing-masing.

3) Kita seharusnya bersyukur kalau Allah masih mau mempercayakan kita berbagai bentuk talenta, meskipun sebenarnya kita menyadari bahwa kita tidak layak untuk menerimanya. Kita lemah, terbatas, berdosa, sering berbuat hal yang bodoh. Itulah namanya anugerah, yang harus kita syukuri dan kita kelola/kembangkan dengan maksimal.

\footnotetext{
${ }^{8}$ Ibid., 224

${ }^{9}$ D.A. Carson, New Bible Commentary, (USA: Intervarsity Press, 1994), 937-938
} 
Missio Ecclesiae, 3 (2), Oktober 2014, 183-198

\section{"NILAI KEPERCAYAAN TUHAN"}

Dalam teks ini kepercayaan yang diberikan oleh sang tuan kepada hamba-hambanya adalah berupa talenta. Istilah talenta dalam bahasa Yunani berasal dari kata ta, lanta talanta/talanton. Kata ini merupakan kata benda neuter jamak yang menyatakan objek. ta, lanta muncul 14 kali dalam Alkitab Perjanjian Baru. Arti kata talanton adalah suatu ukuran berat yang bervariasi dari 26-36 kg. Kemudian menjadi dasar ukuran uang logam yang nilainya tergantung pada zaman, tempat dan jenis logamnya. Dengan demikian nilainya selalu cukup tinggi. Satu talanton perak senilai 6000 dinar, yaitu upah 6000 hari seorang buruh. Sedangkan satu talanton emas bernilai 30 kali lipat dari satu talanton perak. ${ }^{10}$ Untuk mendapatkan satu talenta perak, maka seseorang harus bekerja selama lebih dari enam belas tahun, sedangkan untuk memperoleh satu talenta emas, seseorang harus bekerja selama lebih dari empat ratus sembilan puluh tiga tahun (tidak ada manusia sekarang yang mencapai usia 493 tahun).

Kita dapat membayangkan bahwa seseorang akan menghabiskan masa hidupnya untuk mendapatkan lima talenta perak, yaitu lebih dari delapan puluh tahun, sedangkan untuk mendapatkan lima talenta emas sangatlah mustahil karena tidak ada seorangpun manusia yang pernah hidup di dunia selama dua ribu empat ratus tahun. New International Version menerjemahkan talents of money. Berdasarkan keterangan Ensiklopedi Alkitab Masa Kini, 1 talenta sama dengan 960 dolar Amerika setara dengan 2.160.000 rupiah. ${ }^{11}$ Dalam konteks nats ini yang menjadi tekanan utamanya bukan besarnya jumlah talenta yang diberikan, melainkan besarnya nilai dari talenta yang dberikan sang tuan kepada hambanya. Vines mencatat bahwa talenta merupakan sesuatu pemberian (hadiah) atau kemampuan, secara khusus dalam menafsirkan perumpamaan. ${ }^{12}$ Senada dengan hal tersebut, Carson menulis demikian:

It is this parable which has given the word a metaphorical meaning in English, as it has been applied to the God given gifts

\footnotetext{
${ }^{10}$ Hasan Sutanto, Perjanjian Baru Interlinear dan Konkordansi Perjanjian Baru Jilid II, (Jakarta: LAI, 2006), 744

11 J.D. Douglas, Ensiklopedi Alkitab Masa Kini Jilid II M-Z, (Jakarta: Yayasan Komunikasi Bina Kasih/OMF, 2005), 519 (kemungkinan ini perhitungan sesuai dengan tahun ditulisnya ensiklopedi ini, yaitu tahun 1988 atau tahun cetakan pertama, yaitu tahun 1995)

12 W.E. Vine, Vine's Complete Expository Dictionary, (Nashville: Thomas Nelson, Inc.,
} 1996), 617 
and abilities which we are responsible for using. This is probably a valid application of the story, but we should not imagine that the Greek word itself conveys anything more than its literal monetary meaning. ${ }^{13}$

Hal tersebut menunjukkan bahwa segala sesuatu yang dimiliki oleh manusia adalah sebagai hadiah/pemberian Allah dan hadiah/pemberian Allah memiliki nilai yang sangat spektakuler, apalagi jika dikelola dengan baik dan benar. Sekali lagi saya ingin menekankan kembali bahwa Tuhan menyerahkan kepada kita kepercayaan sesuai dengan kemampuan kita masing-masing. Tuhan sangat mengenal siapa manusia karena Dialah yang menjadikannya sesuai dengan inisiatif, cara dan tujuan Allah sendiri. Tuhan mengetahui potensi tiap-tiap orang karena Dia sendirilah yang memberikannya kepada manusia. Smith menyebut talenta sebagai kecakapan. Dia menyatakan bahwa kita bukan hanya memiliki talenta, tetapi juga memiliki potensi untuk mengembangkannya sehingga dapat mengalami kemajuan yang sangat berarti. ${ }^{14}$ Berarti manusia yang sehat dan normal mempunyai potensi yang luar biasa yang telah Tuhan tanamkan dalam hidupnya.

\section{"BENTUK-BENTUK KEPERCAYAAN TUHAN"}

Istilah uang pada ayat 16 dalam terjemahan NIV adalah money namun dalam bahasa Yunani ditulis auvtoi/j (autois) yang menunjuk pada talenta yang sudah diterima oleh hamba dari tuannya. Istilah uang pada ayat 18 adalah avrgu, rion (argurion) dalam bentuk tunggal dan pada ayat 27 avrgu, ria (arguria) dalam bentuk jamak yang artinya perak, uang perak, uang. Argurion Adalah sejenis uang logam perak yang bernilai empat (drakhme), atau sama dengan upah rata-rata sehari buruh. ${ }^{15}$ Memang dalam teks ini hal yang dipercayakan sang tuan kepada hambanya adalah harta berupa uang (materi).

Bentuk-bentuk talenta (kepercayaan) Tuhan kepada manusia berbedbeda. Namun jika kita melihat lebih luas lagi, sesungguhnya Tuhan bukan hanya mempercayakan bagi manusia harta kekayaan yang bersifat materi, yang

${ }^{13}$ D.A. Carson, New Bible Commentary, (USA: Intervarsity Press, 1994), 938

${ }^{14}$ M. Blaine Smith, Anda Unik di Mata Tuhan, (Bandung: Lembaga Literatur Baptis, 2000), 126

${ }^{15}$ Ibid., 111 
dapat dilipatgandakan dengan usaha dan kerja keras yang aktif. Tetapi juga segala sesuatu yang diberikan Allah kepada manusia dapat dikelola dan mendatangkan keuntungan yang sangat besar bagi manusia. Segala sesuatu yang dimaksudkan di sini bukan hanya yang bersifat material, namun juga pemikiran (mind), kemampuan (ability) dalam berkreasi.

Manusia dapat mengembangkan talenta itu melalui profesi yang dimilikinya. Sesungguhnya semua profesi di hadapan Tuhan adalah sama mulianya karena profesi itu adalah pemberian Tuhan yang mulia. Jadi tidak ada profesi yang rendah, sekalipun itu buruh kecil dan kasar. Pada suatu acara hari doa di yayasan dimana saya melayani, kami sungguh berdecak kagum ketika mendengar dan memperhatikan seorang tukang sampah mempresentasikan karyanya, yang mana ia berhasil menciptakan satu sistem pengolahan sampah setelah dia melakukan berbagai penelitian yang kelihatannya sangat sederhana, namun cukup penting bukan hanya bagi kesehatan manusia, juga memiliki nilai ekonomi yang cukup menguntungkan, bahkan berdampak bagi pelestarian bumi yang Tuhan ciptakan ini.

Belakangan ini, media menunjukkan sesuatu yang luar biasa. Sampahsampah rumah tangga yang tidak dapat didaur ulang, ternyata dapat diolah dan dijadikan berbagai bentuk peralatan rumah tangga, peralatan khusus untuk lakilaki, perempuan termasuk anak-anak (misalnya: keranjang pakaian, keranjang belanja, tempat sampah, tas wanita, tas sekolah, rak gantungan sepatu, travelbag, dan lain-lain). Sampah-sampah rumah tangga dapat diolah menjadi bentuk apapun yang diinginkan, yang dapat berguna, yang juga memiliki kualitas eksport dengan omset ratusan juta bahkan miliaran rupiah.

Selain itu, segala yang dimiliki oleh manusia mulai dari ujung rambut sampai ujung kuku memiliki nilai ekonomi yang bisa dieksplorasi, yang mendatangkan keuntungan besar bagi orang tersebut juga bagi orang lain. Contohnya: seorang peraga busana yang ingin menata dan menghias kukunya, berdampak ekonomis baginya karena dia mendapatkan upah yang besar pada saat tampil sempurna di catwalk. Sedangkan pihak salon yang menata dan menghias kuku itu juga mendapatkan keuntungan ekonomis, perancang busana juga akan menerima pesanan-pesanan busana rancangannya yang tentunya akan mendatangkan untung besar baginya, dan seterusnya. Keuntungan besar itu baru dilihat dari segi eksplorasi kuku jari tangan dan kaki dan tentunya masih banyak hal lain lagi yang dapat dilakukan. 
Missio Ecclesiae, 3 (2), Oktober 2014, 183-198

Apa yang ingin saya tekankan melalui hal-hal tersebut? Penekanan saya bukan pada hasil yang diperoleh atau dicapai oleh manusia dari apa yang dikerjakan dan dikelola. Hal yang paling penting adalah bagaimana seseorang itu menemukan potensi/talenta yang dianugerahkan Tuhan dan mengelolanya serta mengembangkannya dengan baik dan maksimal. Persoalan yang sering kita kita lihat ataupun mungkin kita alami bahwa seringkali manusia itu tidak menemukan potensi dirinya sebagai talenta dari Tuhan sehingga ia membiarkan dirinya selalu berada di di bawah kebodohan, kemiskinan, ketidakmampuan/ ketidak-berdayaan, ketidak-tahuan dan lain sebagainya. Kemudian kebodohan itu diberi label/nama "nasib" dengan ungkapan "Yah, memang sudah seperti itu, mau bilang apa lagi?" Kita harus menyadari bahwa dalam diri setiap orang pasti ada kekuatan, baik itu kekuatan spiritual, intelektual, fisikal (jasmani), psikologikal, sosial ataupun kekuatan yang lainnya. Oleh sebab itu, setiap orang percaya harus menemukan talentanya, melatihnya dan mempergunakannya secara maksimal.

"CARA MENGELOLA KEPERCAYAAN TUHAN"

Istilah "menjalankan" diterjemahkan Hasan Sutanto "berdagang". Dalam bahasa Yunani hvrga, sato (ergasato) dari kata dasar h.rgasomai. (ergazomai) yang berarti bekerja, berdagang, berbuat, menghasilkan. Kata ini muncul sebanyak 41 kali dalam Perjanjian Baru. ${ }^{16}$ Ergasato adalah kata kerja orang ke-3 tunggal Aorist Middle Indikatif. ${ }^{17}$ Bentuk kata ini memberi pengertian bahwa "menjalankan" adalah suatu pekerjaan yang hanya satu kali di masa lampau, menekankan kesungguhan dan dedikasi. Juga dapat berarti "mulai menjalankan", menunjukkan tindakan yang langsung dilakukan setelah menerima kepercayaan yang diberikan.

Teks ini memberikan pengertian bahwa menjalankan uang yang dimaksud lebih kepada konotasi bekerja keras dengan memanfaatkan uang yang ada untuk menghasilkan keuntungan yang besar. Hal itu dapat dilakukan dengan cara berdagang, atau menciptakan kreasi yang baru dengan modal yang sudah ada. Tiga tahun terakhir ini, di televisi banyak disiarkan tentang industri rumah tangga yang menghasilkan mutu dan nilai seni yang berkualitas ekspor.

\footnotetext{
${ }^{16}$ Hasan Sutanto, Perjanjian Baru Interlinear dan Konkordansi Perjanjian Baru Jilid II..., 311

${ }^{17}$ Hasan Sutanto, Perjanjian Baru Interlinear dan Konkordansi Perjanjian Baru Jilid I ..., 147
} 
Missio Ecclesiae, 3 (2), Oktober 2014, 183-198

Kendatipun bahan dasar yang dipakai adalah limbah, namun dapat menghasilkan keuntungan yang sangat mencengangkan.yang terutama harus disadari bahwa dalam diri setiap orang ada potensi besar yang harus dikembangkan.

Sedangkan dalam ayat 27 dituliskan keheranan sang tuan kepada si hamba yang tidak melakukan apapun untuk mengembangkan talenta yang dipercayakan kepadanya. Istilah "orang yang menjalankan uang" dan dalam bahasa Yunani adalah trapezi,taij (trapezitais) dari kata dasar trapezithj (trapezites) yang muncul hanya dalam nats ini dari kitab Perjanjian Baru, yang memiliki pengertian orang-orang yang mengusahakan bank atau orang-orang yang bekerja di bank. ${ }^{18}$ Dengan demikian, sesungguhnya sekalipun hamba yang ketiga hanya menerima satu talenta, dia bisa saja menyimpan uang itu di bank sehingga berbunga. Atau dengan kata lain uang itu dapat disimpan sebagai deposito, karena itu sama dengan meminjamkan uang ke bank untuk dikelola oleh pihak bank dan keuntungan bank itu juga menjadi keuntungan orang yang menyimpan uang.

Orang yang menemukan potensi dirinya dengan baik, dan ia tahu bahwa hal itu dianugerahkan/ dipercayankan Tuhan kepadanya, maka ia pasti tahu apa yang harus dilakukannya dengan potensi tersebut. DR. Petrus Octavianus adalah salah seorang Kristen, yang menyerahkan hidupnya menjadi seorang hamba Tuhan. Beliau seorang hamba Tuhan yang sungguh-sungguh menemukan talenta yang luar biasa, yang Tuhan percayakan kepada beliau. Beliau tidak hanya bangga dengan begitu banyak kekhususan yang Tuhan berikan kepada beliau, melainkan beliau bekerja keras, giat dalam pekerjaan Tuhan, selalu melihat setiap tantangan sebagai peluang untuk terus maju. ${ }^{19}$ Beliau seorang pemimpin yang visioner, dan suara kenabiannya menembus sampai ke pemerintahan di negara ini, ${ }^{20}$ bahkan menyuarakan suara kenabian sampai kepada pemimpin dunia. ${ }^{21}$ Beliau memiliki kekhususan yang tidak dimiliki oleh hamba Tuhan yang lain, dan beliau disejajarkan dengan pemimpin-pemimpin lainnya yang memberikan dampak bagi bangsa ini dan bagi dunia.

\footnotetext{
${ }^{18}$ Hasan Sutanto, Perjanjian Baru Interlinear dan Konkordansi Perjanjian Baru Jilid II..., 762

${ }^{19}$ Baca Buku Biografi Petrus Octavianus, "Hidupku Hanya Oleh Anugerah"

${ }^{20}$ Baca Buku "Menuju Indonesia Jaya dan Indonesia Adi Daya...."

${ }^{21}$ Baca Buku "Surat Kepada Presiden Amerika George W. Bush, Jr."
} 
Missio Ecclesiae, 3 (2), Oktober 2014, 183-198

Setiap orang Kristen memiliki keunikan/kekhususannya masing-masing dan memiliki kemungkinan untuk maju di berbagai bidang. Kita harus mewaspadai dan menolak mentalitas karyawan, yang pada umumnya dimiliki oleh penduduk negara ini. Lulus SD, SMP, SMU, S1 kemudian mencari pekerjaan dan hidup berharap pada upah.

Setiap orang Kristen harus memiliki kreativitas karena Allah kita adalah Allah yang kreatif, berani berinovasi dan menciptakan manuvermanuver yang berdampak spektakuler. Namun demikian, ada proses demi proses pembelajaran yang harus kita jalani. Kita harus terus belajar dari Tuhan melalui buku-buku, melalui situasi-situasi yang kita hadapi, dan melalui orangorang yang ada di hadapan kita. Karena itu, jika kita adalah petani, harus maksimal sebagai petani; jika kita adalah pedagang, harus maksimal sebagai pedagang; jika kita pegawai negeri atau swasta, harus maksimal sebagai pegawai; jika kita adalah pemimpin, harus maksimal menjalankan kepemimpinannya; dan lain sebagainya.

\section{Apa yang akan dilakukan pada saat kiamat datang}

\section{"TUHAN MENUNTUT PERTANGGUNGAN JAWAB"}

Pada saat tuan itu kembali pada waktu yang tidak diberitahukan sebelumnya, ia memanggil hamba-hambanya untuk melakukan perhitungan. Dengan kata lain, sang tuan datang dengan tiba-tiba tanpa ada isu-isu ataupun tanda-tanda sebelumnya. Pada perumpamaan sebelumnya dalam pasal 24:36, 44, 50; 25:13, Tuhan Yesus telah menyatakan berulang kali bahwa kedatangan Tuhan yang kedua kali tidak diketahui oleh siapapun kecuali oleh Bapa sendiri.

Dalam bahasa Yunani, kata "perhitungan" terdiri dari dua kata yaitu sunai, rei (sunairei), dan 10,gon (logon) yang mana kedua kata ini selalu dipakai bersama-sama yaitu dalam Matius 18: 23 dan 24, Matius 25:19 dan ketiga teks tersebut berbicara tentang perumpamaan untuk mengajarkan tentang kerajaan sorga. Kata sunairei dari akar kata sunai, rw (sunairo) yang berarti memeriksa (catatan keuangan) yang hanya muncul 3 kali dalam Perjanjian Baru, Kata logon dari kata dasar logoj (logos) muncul sebanyak 330 kali dalam Perjanjian Baru dengan banyak pengertian, di antaranya laporan, buku, catatan keuangan, pertanggungjawaban, dan lain-lain. Dalam NIV diterjemahkan settled accounts artinya membereskan 
Missio Ecclesiae, 3 (2), Oktober 2014, 183-198

laporan/catatan/rekening, sedangkan dalam KJV diterjemahkan reckoneth yang artinya perhitungan. Selain itu, hal yang menarik, kata ini dalam bentuk orang ke-3 tunggal Present Aktif Indikatif yang menunjukkan suatu tindakan yang langsung dilakukan pada saat itu juga. Jadi, kata ini dapat ditafsirkan demikian:

1) Pada waktu tuannya pulang, langsung memeriksa catatan keuangan, laporan, pertanggungjawaban hamba-hambanya. Tidak diberikan waktu untuk membereskannya lagi.

2) Tuannya tidak mengulur-ulur waktu untuk meminta pertanggungjawaban hamba-hambanya. Sehingga tidak ada waktu untuk membuat laporan atau pembukuan yang menyeleweng.

Oleh sebab itu, tidak ada alasan dan tidak ada waktu untuk bermalas-malasan. Karena akan tiba saatnya, Tuhan akan meng-audit kita sesuai dengan apa yang telah dipercayakan kepada kita. Maka tiap saat, tiap detik kita harus menyiapkan diri untuk itu. Jika Tuhan datang, waktu untuk hidup dan bekerja selesai, maka siap atau tidak siap, hidup kita harus dipertanggungjawabkan kepada Tuhan.

\section{“HAMBA MEMPERTANGGUNGJAWABKAN KEPERCAYAAN TUHAN"}

Segala sesuatu yang dianugerahkan Tuhan kepada orang percaya bukan berarti tanpa pertanggungjawaban/ perhitungan. Hamba yang dipercayakan lima talenta telah menghasilkan lima talenta, hamba yang dipercayakan dua talenta telah menghasilkan dua talenta, sedangkan hamba yang menerima satu talenta tidak menghasilkan apapun yang disebut keuntungan. Berdasarkan hal tersebut maka dapat diambil kesimpulan bahwa hamba yang menerima satu talenta itu bukan karena bodoh (tidak memiliki kemampuan), bukan karena malas melainkan tidak taat dan jahat. Hal ini dapat dilihat dari jawabannya kepada tuannya saat dimintai pertanggungjawaban, demikian: "Tuan, aku tahu bahwa tuan adalah manusia yang kejam yang menuai di tempat di mana tuan tidak menabur dan memungut dari tempat dimana tuan tidak menanam." (ayat 24).

Setiap keputusan dan tindakan pasti ada konsekuensinya. Hamba yang menerima lima dan dua talenta telah bekerja keras, telah mengelola talenta itu secara maksimal. Kita tidak pernah tahu pasti akan waktu dan harinya Tuhan 
Missio Ecclesiae, 3 (2), Oktober 2014, 183-198

Yesus datang kedua kalinya, tetapi yang harus pasti bagi kita sekarang adalah bahwa kita tiap-tiap hari bekerja keras dan maksimal dalam mengaktualisasikan diri dalam melayani pekerjaan Tuhan sesuai dengan karunia kita masing-masing, di bidang kita masing-masing.

\section{"TUHAN MEMBERI UPAH"}

\section{1) Kelimpahan}

Para hamba yang memutuskan untuk melipatgandakan talenta yang dipercayakan oleh tuannya mendapat nilai A (Baik Sekali) dan predikat sebagai Hamba yang Baik dan Setia. Hamba yang mengusahakan lima talenta dan menguntungkan lima talenta diberi berkelimpahan.

Berkelimpahan berasal dari bahasa Yunani perisseutesetai ${ }^{22}$ dengan kata dasar perisseuo muncul 39 kali dalam Perjanjian Baru ${ }^{23}$ yang artinya berlimpah, berkelebihan, berlimpah-limpah, bertambah, maju, ada keuntungan, melimpahkan, membuat bertambah. Dalam NIV dan KJV diterjemahkan abundance yang artinya kelimpahan atau keadaan berlimpahlimpah. Kata ini digunakan dalam bentuk kata kerja orang ke-3 tunggal Futurum Pasif Indikatif. ${ }^{24}$ Bentuk Futurum Indikatif selalu berbicara mengenai masa depan maka artinya adalah akan dibuat berlimpah, atau dengan kata lain akan diberikan lebih banyak dari hasil yang telah didapatkan dengan jerih payahnya. Selain itu, hamba yang baik dan setia itu mendapatkan kesempatan yang lebih besar sebagaimana yang dikatakan Sang Tuan: "engkau telah setia dalam perkara kecil, Aku akan memberikan kepadamu tanggung jawab dalam perkara yang besar. Dengan demikian, jaminan masa depan bagi setiap hamba yang bekerja keras dalam mempertanggungjawabkan kepercayaan Tuhan berupa talenta-talenta yang dikaruniakan sangat pasti terjamin. Kelimpahan yang ia terima menyangkut reputasinya yang juga akan mengangkat dia ke posisi yang lebih tinggi.

\section{2) Hukuman}

\footnotetext{
$22 \mathrm{Ibid}$

${ }^{23}$ Hasan Sutanto, Perjanjian Baru Interlinear dan Konkordansi Perjanjian Baru Jilid II..., 632

${ }^{24}$ Hasan Sutanto, Perjanjian Baru Interlinear dan Konkordansi Perjanjian Baru Jilid I ..., 147
} 
Missio Ecclesiae, 3 (2), Oktober 2014, 183-198

Hamba yang menerima satu talenta tidak menghasilkan apapun yang disebut keuntungan. Hamba yang memutuskan untuk menyembunyikan talenta yang dipercayakan itu mendapat nilai $\mathrm{F}$ (Fail=Gagal) dengan predikat Jahat dan Malas dan ditambahkan lagi pada ayat 30 disebut sebagai hamba yang tidak berguna. Berdasarkan hal tersebut maka dapat diambil kesimpulan bahwa hamba yang menerima satu talenta itu bukan karena bodoh (tidak memiliki kemampuan), bukan hanya karena malas melainkan tidak taat dan jahat. Hal ini dapat dilihat dari jawabannya kepada tuannya saat dimintai pertanggungjawaban, demikian: "Tuan, aku tahu bahwa tuan adalah manusia yang kejam yang menuai di tempat di mana tuan tidak menabur dan memungut dari tempat dimana tuan tidak menanam." (ayat 24). Dengan demikian, Alkitab juga mencatat bahwa akibat dari sikap dan keputusan yang salah dari hamba tersebut adalah: pertama, talenta yang dipercayakan sebelumnya diambil dari padanya, kedua dicampakkan ke dalam kegelapan yang paling gelap.

\section{PENUTUP}

Sebagai penutup dari khotbah saya ini, saya ingin menegaskan beberapa hal untuk senantiasa kita renungkan dan lakukan dalam kehidupan kita seharihari, dimana pun Tuhan percayakan kita melayani Dia, yaitu:

\section{Ucapan Syukur}

Mari kita menjalani hidup ini dengan penuh ucapan syukur, karena Tuhan telah mengaruniakan talenta-Nya kepada kita masing-masing.

\section{Menemukan Talenta}

Siapapun kita, terutama yang percaya dan mengenal Tuhan Yesus, pasti ada talenta tertentu yang Tuhan telah karuniakan kepada kita masingmasing. Maka langkah pertama yang dapat kita lakukan adalah menemukan talenta apa yang Tuhan berikan kepada kita masingmasing.

\section{Bekerja Keras}

Kita harus meninggalkan kebiasaan santai, malas, hidup tanpa tujuan dan mari kita mengembangkan kebiasaan "berani bermimpi", berani melangkah dan bekerja keras, maksimal bahkan berusaha sampai "sempurna". Kita harus berani berinovasi melayani pekerjaan Tuhan.

\section{Senantiasa Siap Diaudit}

Mulai dan akhiri setiap hari dengan ucapan syukur dan menyerahkan diri kepada Tuhan Yesus, jalani hidup sesuai dengan rencana dan 
Missio Ecclesiae, 3 (2), Oktober 2014, 183-198

kehendak Tuhan Yesus. Apabila Tuhan Yesus datang secara tiba-tiba, kita didapati berkenan di hadapan-Nya. Amin.

\section{KEPUSTAKAAN}

Carson, D.A.,

1994 New Bible Commentary. USA: Intervarsity Press.

Catherine, Soanes; Stevenson, Angus,

2004 Concise Oxford English Dictionary 11th ed. Oxford : Oxford

University Press

Crowther, Jonathan

1995 Oxford Advanced Learner's Dictionary. England: Oxford University Press.

Douglas, J.D.,

2005 Ensiklopedi Alkitab Masa Kini Jilid II M-Z. Jakarta: Yayasan Komunikasi Bina Kasih/OMF.

Octavianus, Petrus

2005 Menuju Indonesia Jaya (2005-2030) Dan Indonesia Adidaya (2030-2055). Batu: Departemen Literatur YPPII.

2007 Hidupku Hanya Oleh Anugerah TUHAN. Batu: Departemen Multimedia YPPII.

2003 Surat Kepada Presiden Amerika George W. Bush, Jr. Batu: Departemen Literatur YPPII.

Smith, M. Blaine

2000 Anda Unik di Mata Tuhan. Bandung: Lembaga Literatur Baptis.

Sutanto, Hasan

2006 Perjanjian Baru Interlinear dan Konkordansi Perjanjian Baru Jilid I. Jakarta: LAI.

2006 Perjanjian Baru Interlinear dan Konkordansi Perjanjian Baru Jilid II. Jakarta: LAI.

Wongso, Peter

$2000 \quad$ Hermeneutika Eskatologi. Malang: SAAT

Vine, W.E.,

1996 Vine's Complete Expository Dictionary. Nashville: Thomas Nelson, Inc.

http://kamusbahasaindonesia.org/kiamat\#ixzz2K5CIqBq2 